\title{
Oral treatment of subacute bacterial endocarditis in children
}

\author{
B. PHILliPS AND G. H. WATSON
}

From the Royal Manchester Children's Hospital, and Department of Child Health, Manchester University

SUMMARY Fourteen episodes of subacute bacterial endocarditis in 11 children were successfully treated with antibiotics, which in 13 cases were given largely by mouth. It is suggested that oral treatment of bacterial endocarditis should be considered for children who are only moderately but not severely ill, and who have sensitive organisms.

Most published reports of subacute bacterial endocarditis have stressed the need for parenteral rather than oral treatment. A few early reports showed successful treatment with oral penicillins (Gray et al., 1964; Gray, 1969), but these regimens have never achieved popularity. We present 14 episodes of subacute bacterial endocarditis in children successfully treated with antibiotics given largely by mouth, and discuss why some patients may be better treated with oral rather than parenteral antibiotics.

\section{Patients and methods}

Between 1960 and 1975, 14 episodes of subacute bacterial endocarditis (SBE) in children have been

Received 4 June 1976 treated at this hospital, all but the first 2 being under the care of one of us (G.H.W.). Details of those treated orally are given in the Table. In all 14 cases repeated blood cultures were positive; in 8 cases Streptococcus viridans was cultured, in 3 others streptococci or enterococci, and in 3 staphylococci. In 13 episodes the age and clinical manifestations were characteristic. Case 7 may seem less certain because of the rarity of SBE in infancy (Macaulay, 1954), but there were unexplained fever and persistently positive blood cultures growing Strep. viridans. On admission 4 children had evidence of pulmonary emboli, one had nephropathy, and one developed meningitis with a sterile cerebrospinal fluid a few days after starting treatment.

Treatment with an appropriate antibiotic was

Table Details of patients

\begin{tabular}{|c|c|c|c|c|c|c|c|c|c|}
\hline \multirow{2}{*}{$\begin{array}{l}\text { Case } \\
\text { no. }\end{array}$} & \multirow{2}{*}{$\begin{array}{l}\text { Age } \\
(y r)\end{array}$} & \multirow{2}{*}{$\begin{array}{l}\text { Underlying } \\
\text { lesion }\end{array}$} & \multirow[b]{2}{*}{ Organism } & \multicolumn{4}{|l|}{ Treatment } & \multirow[b]{2}{*}{$\begin{array}{l}\text { Serum } \\
\text { levels } \\
\text { of drug } \\
(\mu g / \mathrm{ml})\end{array}$} & \multirow{2}{*}{$\begin{array}{l}\text { MIC of } \\
\text { drug } \\
\text { against } \\
\text { organism } \\
(\mathrm{mg} / \mathrm{ml})\end{array}$} \\
\hline & & & & Drug & $\begin{array}{l}\text { Daily } \\
\text { dose } \\
(g)\end{array}$ & $\begin{array}{l}\text { Duration } \\
(w)\end{array}$ & $\begin{array}{l}\text { Bactericidal } \\
\text { dilution of } \\
\text { serum }\end{array}$ & & \\
\hline $\begin{array}{r}1 \\
2 \\
3 \\
4 \\
5 \\
6 \\
7 \\
8 \\
9 \\
10 \\
11 \\
12\end{array}$ & $\begin{array}{l}11 \\
12 \\
15 \\
10 \\
15 \\
11 \\
6 \mathrm{~m} \\
5 \\
7 \\
8 \\
6 \\
7 \frac{1}{2}\end{array}$ & $\begin{array}{l}\text { CTGA, VSD, PS } \\
\text { VSD, CTGA, PS } \\
\text { VS̈ " " } \\
\text { Tetralogy } \\
\text { Mitral incompetence } \\
\text { TGA, small PDA } \\
\text { VSD, banded } \\
\text { VS̈D " } \\
\text { Tetralogy } \\
\quad, \text { " }\end{array}$ & $\begin{array}{c}\text { Strep. } \\
\text { viridans } \\
", \\
", \\
", \\
", \\
\text { ", ", } \\
\text { Staph. aureus } \\
\text { Strep. faecalis } \\
\text { Staph. albus } \\
\text { Microaerophilic } \\
\text { streptococcus } \\
\text { Staph. aureus }\end{array}$ & $\begin{array}{c}\text { Erythromycin } \\
\text { Penicillin V } \\
\text { Ampicillin } \\
\text { ", } \\
\text { ", } \\
\text { ", } \\
\text { Cloxacillin } \\
\text { Ampicillin } \\
\text { ", }\end{array}$ & $\begin{array}{l}1 \\
2 \\
4 \\
8 \\
8-16 \\
8 \\
2 \\
4 \\
7 \cdot 56 \\
2 \\
2 \\
2\end{array}$ & $\begin{array}{r}8 \\
6 \\
6 \\
6 \\
7 \\
8 \\
8 \\
6 \\
12 \\
6 \\
5 \\
6\end{array}$ & $\begin{array}{l}- \\
- \\
- \\
- \\
- \\
- \\
- \\
1 / 16 \\
- \\
1 / 2 \text { to } 1 / 64\end{array}$ & $\begin{array}{l}- \\
\overline{-} \\
10 \\
10 \\
3 \cdot 7 \\
10 \\
5 \\
3 \\
1 \cdot 6 \\
-5 \cdot 0\end{array}$ & $\begin{array}{l}\overline{-} \\
\overline{0.06} \\
\overline{0.05} \\
\overline{-} \\
0.03 \\
0.01 \\
\overline{0.02}\end{array}$ \\
\hline
\end{tabular}

CTGA = congenital corrected transposition of great arteries; VSD=ventricular septal defect; TGA =transposition of great arteries; PS = pulmonary stenosis; PDA = persistent ductus arteriosus. MIC= minimum inhibitory concentration. 
started on diagnosis. Case 14, who had very severe general symptoms and whose illness due to an enterococcus began 6 weeks after a corrective operation for tetralogy, was given intravenous treatment for 2 months. Case 13 was treated intravenously for 2 weeks because he objected violently to oral medication, though in the subsequent 6 weeks he was treated by an indwelling orogastric tube which he accepted even while up and about.

In 6 cases treatment was entirely oral, and in another 6 , including the more severely ill as well as Case 6 with rheumatic heart disease, medication was given parenterally for the first 2 or 3 days. However, when no severe general or abdominal symptoms were present which would suggest inadequate absorption, drugs were given only by mouth. In 2 cases dilutions of serum up to $1 / 16$ and $1 / 64$ killed the cultured organisms; in others serum antibiotic levels 3 to 4 hours after the previous dose exceeded the median inhibitory concentration (MIC) of the drug for the cultured organism by factors of 30-250. Treatment was given for 6 to 8 weeks in most cases, but was longer in 2 cases because of the nature of the organism or previous surgery. Some children who seemed physically well and whose erythrocyte sedimentation rate had fallen were allowed home for the latter part of their treatment, with frequent supervision.

\section{Results}

The 10 children treated orally recovered from their attacks of SBE with no permanent sequelae or change in cardiac status or signs, and all have been followed up for periods of 1 to 15 years. Case 14, treated intravenously, also recovered from SBE but died later from mechanical causes. 3 children treated orally had second attacks of SBE; we feel that these were not relapses following inadequate treatment because in 2 cases a different organism was cultured 9 months and 2 years, respectively, after the first episode, while in the third child the attacks were 4 years apart.

No significant complications of treatment were encountered and in particular no child had vomiting, troublesome anorexia, or diarrhoea, or 'superinfection' with other organisms.

\section{Discussion}

The clinical and bacteriological spectrum of infective endocarditis has changed over the last 20 years. From a predominant involvement of young adults with rheumatic heart disease emphasis has passed to older adults, unusual and opportunist organisms, and association of the disease with invasive pro- cedures. In children there is now found, as in this series, an underlying congenital cardiovascular lesion in $90 \%$ of the cases; however, the commonest organism is still Strep. viridans, the next common being staphylococci and enterococci (Nadas and Fyler, 1972).

Despite much discussion no final conclusion has been reached about the optimum duration of treatment. In cases due to penicillin-sensitive Strep. viridans short courses (e.g. 2 weeks) have been effective (Tan et al., 1971), but though there is evidence that larger doses of antibiotics permit a shorter period of treatment than the 6 or 8 weeks used 25 years ago, in general 4 weeks' treatment is advised for such cases (Hayward, 1973; Weinstein, 1970). Longer periods (4 to 6 weeks) have been advised for more resistant streptococci and other organisms (Kaye, 1973; Weinstein and Schlesinger, 1973). There is anecdotal evidence for occasional superinfection with Gram-negative organisms when oral treatment is continued for even as short a time as 5 or 6 weeks (Weinstein and Schlesinger, 1973), but there is also similar evidence that occasional patients with apparently sensitive organisms need much longer courses for cure (Hayward, 1973). We have felt that there is little hazard in extending oral medication for 2 or more weeks, when no clinical symptoms have been caused, even though in some cases it may be unnecessary.

Oral treatment has been and still is regarded as unsatisfactory (Hayward, 1973; Kaye, 1973), most physicians preferring to use parenteral treatment, probably for the following reasons (Weinstein and Schlesinger, 1973). (1) Extensive past experience has shown good results using parenteral antibiotics. (2) Infection may be caused by an organism for which the best antibiotic may be available only in parenteral form. (3) Oral antibiotics may lead to gastrointestinal irritation. (4) Patients may fail to take the drugs prescribed unless under observation. (5) Antibiotics may be irregularly absorbed from the gut. On the other hand, recommendations for the use of oral antibiotics spring from the desire to avoid pain and anxiety, especially in children with chronic disease who know they may have to return to hospital, and also to reduce the chances of complications, such as abscesses, thrombophlebitis, or septicaemia, arising from injections or indwelling cannulae.

We feel that the contraindications to oral treatment listed above can be circumvented in most children with SBE. Most organisms which cause SBE are treatable by antibiotics which can be given by mouth; gastrointestinal symptoms have not been a problem, and oral treatment can be adequately supervised and safely left to a certain number of parents to continue at home. Absorption from the 
gut has led to adequate serum levels of antibiotics and effective treatment, but may be unreliable in those with severe general or abdominal symptoms. The semisynthetic penicillins are especially reliable, and serum levels after oral doses of these drugs exceed many-fold the median inhibitory concentrations for pathogens commonly found in SBE (Knudsen et al., 1961). Various authors recommend that the serum should be bactericidal in dilutions varying from 1 in 2 (Hayward, 1973) to 1 in 20 (Nadas and Fyler, 1972), and these levels are also possible to achieve.

We feel that if the organism is appropriately sensitive, and if attention is paid to the attainment and maintenance of adequate serum levels and to the response to treatment, most children with bacterial endocarditis may be treated effectively with predominantly oral antibiotics, enabling some of them to be managed at home for the latter part of their treatment, and avoiding the discomfort and complications of long-term parenteral treatment.

\section{References}

Gray, I. R. (1969). Bacterial Endocarditis: Proceedings of a National Symposium. Ed. by P. B. Beeson and M. Ridley. Beecham Research Institute, Brentford.
Gray, I. R., Tai, A. R., Wallace, J. G., and Calder, J. H. (1964). Oral treatment of bacterial endocarditis with penicillins. Lancet, 2, 110-114.

Hayward, G. W. (1973). Infective endocarditis: a changing disease. II. British Medical Journal, 2, 764-766.

Kaye, D. (1973). Changes in the spectrum, diagnosis, and management of bacterial and fungal endocarditis. Medical Clinics of North America, 57, 941-957.

Knudsen, E. T., Rolinson, G. N., and Stevens, S. (1961). Absorption and excretion of 'Penbritin'. British Medical Journal, 2, 198-200.

Macaulay, D. (1954). Acute endocarditis in infancy and early childhood. American Journal of Diseases of Children, 88, 715-731.

Nadas, A. S., and Fyler, D. C. (1972). Pediatric Cardiology, p. 183. Saunders, Philadelphia.

Tan, J. S., Terhune, C. A., Kaplan, S., and Hamburger, M. (1971). Successful two-week treatment schedule for penicillin-susceptible streptococcus viridans endocarditis. Lancet, 2, 1340-1343.

Weinstein, L. (1970). The Pharmacological Basis of Therapeutics, 4th ed., chap. 57. Ed. by L. S. Goodman and A. Gilman. Macmillan, London.

Weinstein, L., and Schlesinger, S. (1973). Treatment of infective endocarditis. Progress in Cardiovascular Diseases, 16, 275-302.

Correspondence to Dr. G. H. Watson, Royal Manchester Children's Hospital, Pendlebury, Nr. Manchester M27 1HA. 